\title{
Switching Expression or Emotion: Emotional Labor Strategy on Negative Word of Mouth, Mediated by Customer Satisfaction
}

\author{
Resekiani Mas Bakar ${ }^{\bowtie}$, Riska Amaliah, Nurul Hidayati \\ Faculty of Psychology, Universitas Negeri Makassar, Makassar, Indonesia
}

\section{Info Article}

History Article:

Submitted 5 July 2019

Revised 18 October 2019

Accepted 19 October 2019

\section{Keywords:}

Negative Word of Mouth; Emotional Labor Strategy; Customer Satisfaction.

\begin{abstract}
This experimental study aimed to examine the effect of emotional labor strategy towards the negative WOM mediated by customer satisfaction. Research of emotional labor context has widely examined its impacts on service employees. The limitations in several studies proved that the opportunity in the indirect effect of emotional labor strategy on negative word of mouth (WOM) is still available. Sixty-two participants were involved in this study and divided into two groups (deep acting versus surface acting) by using videos. PROCESS model moderation proved that emotional labor strategy indirectly affects the negative WOM, mediated by customer satisfaction. This study showed that deep acting strategy can enhance customer satisfaction, therefore the negative WOM can be diminished. In contrast, surface acting strategy affects the decrease of customer satisfaction and thus it can raise the intention of the negative WOM. Emotion modification would be more effective through the deep acting strategy in transmitting the positive emotion for the customer, than modification the expression. The satisfaction felt by the customer will decrease the intention to spread negative information about the service provider to other customers.
\end{abstract}

\section{Mengubah Ekspresi atau Emosi: Strategi Emosi Tenaga Kerja terhadap WOM Negatif Dimediasi Kepuasan Pelanggan}

\begin{abstract}
Abstrak
Studi eksperimen ini bertujuan untuk menguji pengaruh strategi emotional labor terhadap negative WOM dengan dimediasi oleh kepuasan konsumen. Penelitian dalam topik emotional labor telah secara luas menguji dampak bagi karyawan jasa, namun keterbatasan studi yang membuktikan dampak tidak langsung strategi emotional labor terhadap negatif word of mouth (WOM) menjadi peluang dalam penelitian ini. Enam puluh dua orang partisipan ikut serta pada penelitian ini dan terbagi dalam 2 kelompok emotional labor (deep acting versus surface acting) dengan menggunakan video. PROCESS Hayes model moderasi membuktikan bahwa strategi emotional labor berpengaruh secara tidak langsung terhadap negative (WOM) dengan dimediasi oleh kepuasan konsumen. Penelitian ini menunjukkan bahwa strategi deep acting mempengaruhi tingkat kepuasan konsumen, sehingga sikap terhadap WOM negatif dapat diturunkan. Sebaliknya, strategi surface acting dapat menurunkan kepuasan konsumen, sehingga sikap terhadap WOM negatif menjadi lebih tinggi. Modifikasi emosi melalui strategi deep acting lebih efektif dalam menularkan emosi positif bagi konsumen, sehingga menimbulkan penilaian puas dari penerima layanan, dibandingkan memodifikasi ekspresi. Kepuasan yang diterima oleh konsumen akan menurunkan kecenderungan untuk menyampaikan informasi yang negatif tentang penyedia layanan kepada konsumen lainnya.
\end{abstract}

JEL Classification: M3, M31

How to Cite: Bakar, R. M., Amaliah, R., \& Hidayati, N. (2019). Switching Expression or Emotion: Emotional Labor Strategy on Negative Word of Mouth, Mediated by Customer Satisfaction. Jurnal Dinamika Manajemen, 10(2), 162-172. 
Resekiani Mas Bakar et al./ Switching Expression or Emotion: Emotional Labor Strategy on Negative....

\section{INTRODUCTION}

Most of the customers might ever interact with some employees who performed the unsincere service and pretended in fulfilling the request. This situation will lead to customer dissatisfaction and drive people to upload status in social media regarding their disappointment to the service provider, while others tend to convey the story due to the inconvenience to other customers.

Facial expression and vocalization are able to convey the aim and emotion of the service provider to the customers (Neves et al., 2018). The satisfaction that customer accepts from service can induce a pleasant experience, thus, showing this feeling can enhance the employee performance to provide better service (Huang \& Dai, 2010). This tendency due to imitating others' emotion can occur in many circumstances, including service context (Elliott \& Charlton, 2016). This is called emotional contagion. Emotional contagion theory stated that emotional interaction experienced by an individual can spread to others (Hatfield et al., 1993). The service interaction occurs between the employee and the customer not merely depend on the economic transaction, but only involve the emotional feeling between two parties.

Emotional contagion in the business field significantly relate to the interaction between the service provider and customer, either it involves positive or negative emotion ( $\mathrm{Du}$ et al., 2011). Emotional contagion theory demonstrated that the involvement of emotion between two parties could influence each other (Hatfield et al., 1993). When the employee displays the negative emotion for example unsincere smile and less responsive can create dissatisfaction. In contrast, when the employee express the positive emotion, for example sincere, friendly, and responsive, as well as a suit with organization demand, it would affect the positive emotion such as customer satisfaction.

Customer satisfaction can be defined by two basic concepts: satisfaction based on the transaction and cumulative transaction (Suchá- nek et al., 2017). Satisfaction based on the transaction process is the result of customer evaluation from a particular product or service, while the cumulative satisfaction is created by overall customer's experience in using products or services from a company.

Customer satisfaction is a post-consumption evaluation of the individual experience of the product or service which can be influenced by several causes such as customer expectation, sensory experience, and service quality (Iglesias et al., 2011). The ability to understand consumer's behavior and provide the appropriate service as the expectation will bring satisfaction to the customer and lead to the customer's loyalty (Ismoyo et al., 2017). Every company or service provider must fulfill their customer's need by featuring the improvement of relationship quality with customers and organization's value in order to sustain in the current competitive climate (Nguyen et al., 2018).

Customer satisfaction significantly enhances the organization's performance (Taghizadeh et al., 2013). In addition, customer satisfaction allows the organization to increase its brand value and create positive word of mouth (WOM) to the environment. The customer who feels satisfied can provide benefits for a long period through the high service or product request to the company ( $\mathrm{Ha} \&$ Park, 2013). In contrast, low customer satisfaction can inflict several bad behaviors from customers, such as complaining behavior and negative WOM (Szymanski \& Henard, 2001).

The previous study reveals several factors that influence the customer satisfaction are relates to need fulfillment, technical stuff, specifically in service, and the comparison result with other competitors (Suchánek et al., 2015), customer's expectation, customer's judgment regard to the fairness among the other customers, and affection component between employee and customer (Szymanski \& Henard, 2001).

The ability to fulfill customer's need through employee's performance of the company will directly affect the customer satisfaction (Oliver, 1999). Instead of the cognitive component, customer satisfaction also comprises the affective component. Affection effect during the service 
process enables to spread greater impact than the other factors like expectation, performance, and equity. Service is an interaction which not merely involve the economic process, but how to build emotional feeling and maintain a good relationship between service provider and customer. The emotion regulation performed to the customer in the work condition is called emotional labor.

Emotional labor is the employee ability to regulate emotion and feeling to perform the proper face and body display in order to match the organization demands (Hochschild, 1983; Groth \& Hennig-thurau, 2009; Mesmer-magnus, Dechurch \& Wax, 2011; Kruml \& Geddes, 2014). The organization which offers the service must provide the appropriate standard and guidance regarding the "should do" and "not-shoulddo" behavior for their employee during the service process. Emotional labor is a fundamental factor in the service field because the employee will represent the emotion as a part of themselves during service interaction with the customer. Emotional labor involves employee adaptation in increasing, manipulating or suppressing the internal emotion in order to show the appropriate emotional display to fulfill organization demands (Grandey, 2000; Mesmer-magnus et al., 2011). Understanding the impact of emotional labor enables the company to improve its sales target or service request (Cho et al., 2013).

Novelty of this research is the implementation of emotional labor in offering service to customers gives several impacts to the employees, such as health consequences, performance consequences, and attitudinal consequences (Mesmer-magnus et al., 2011). Previous studies have found several impacts of emotional labor on employees such as employee well-being, burnout, self efficacy, self esteem, emotional dissonance, job satisfaction and emotional exhaustion (Brotheridge \& Lee, 2002; Grandey, 2003; Liu et al., 2004; Cho et al., 2013).

\section{Hypothesis Development}

Emotional labor becomes one of the fundamental aspects of service business that focus on the interaction process between the service provider and customer. There are two strategies of employee to perform emotional labor towards other people: deep acting and surface acting. In deep acting strategy, the employee will adjust between internal feeling condition and emotion demand from the organization. Surface acting or sometimes called as the alternative strategy, the employee only modifies their expression in front of the customer without adjusting with the internal condition (Grandey, 2003).

When performing a deep acting strategy, the employee attempts to modify the internal feeling in order to match with organization rules and show empathy in front of the customer. Individual attention will focus on adjusting the external emotion and internal feeling. Whereas performing the surface acting strategy, the employee's purpose is merely preserving the job, not trying to show empathy to the customers. The experience performing surface acting strategy usually leads to encounter emotional dissonance and strain (Hochschild, 1983). Several studies have found that emotional labor affect the customer satisfaction. The employees with deep acting strategy will serve the customer as the standard sincerely, so that it will create the customer satisfaction. In contrast, the employees with surface acting strategy tend to perform their job by the rule without authenticity to interact with customer (Grandey et al., 2005; Hennig-Thurau et al., 2006).

H1: There is a difference in emotional labor strategies on customer satisfaction. The customer in deep acting strategy will be more satisfied than the customer of surface acting.

Service basically is a relationship between provider (employee) and consumer. The process in spreading the informal type of communication among the customers as the result of their assessment and evaluation during experiencing the service process from a certain institution is called as WOM (Vázquez-Casielles et al., 2013; Casidy \& Shin, 2015).

WOM is a fundamental factor in the company's success. WOM can shape the at- 
titude, purchase intention, and purchase behavior to the consumers (Wangenheim, 2005). WOM can influence consumer's behavior and attitude (Yasvari et al., 2012). It has a greater impact than advertisement and other contents in the media (Keller, 2007; King et al., 2014).

There are two types of WOM: positive WOM and negative WOM. These two types of WOM are caused by several factors, such as service quality of company, customer satisfaction, and certain values represented by the organization, brand commitment, private complaining, trust, service quality, values, satisfaction or dissatisfaction towards the product or service (Mazzarol et al., 2007; Vázquez-Casielles et al., 2013). The customer who experienced the unpleasant service from the service provider cause the dissatisfaction and this situation will lead to the complaining behavior and negative WOM (Szymanski \& Henard, 2001). The positive WOM which encourages the brand value, while the negative WOM discourages the brand value in the customer's perspective (East et al., 2008).

In emotional labor studies, most researched only focused on the effects of customer satisfaction. Whereas the emotional labor performed by the employee during service encounter could induce the information spread among customers. This study proposed that deep acting strategy enhances the customer satisfaction, it will decrease the negative WOM. In contrast, surface acting strategy leads to the increase of negative WOM.

$\mathrm{H} 2$ : There is a difference in emotional labor strategies on negative WOM. The customer in deep acting strategy will less involve in negative WOM than the customer of surface acting strategy.

The emergence of WOM is caused by customer satisfaction or dissatisfaction after using the product or experiencing the service. When a customer feels satisfied towards the service or offered product from the company, the tendency to properly behave towards the company is possible to occur, because the customer has obtained the positive reinforcement to engage in the business process.

The previous study demonstrated that customer satisfaction significantly affect WOM (Ranaweera \& Prabhu, 2003). The research on customer satisfaction and WOM is not a new topic, although the study about factors affecting WOM mostly rely on customer satisfaction impact. Similarly, In the context of service, the role of customer satisfaction should be considered as the crucial factors after the employees' performance to attract more customers by spreading the positive WOM and avoid the negative WOM. The limitation of the study which have prooved the customer satisfaction role on negative WOM become hte opportunity in this study. This gap provides the opportunity for the researchers to investigate the indirect effect of emotional labor strategy on negative WOM, through customer satisfaction as a mediation variable.

H3: There is an indirect effect of emotional labor strategy on negative WOM, through customer satisfaction as a mediation.

Several experiment and non-experiment studies have found that emotional labor strategy affects customer satisfaction (HennigThurau et al, 2001; Grandey et al., 2005). However, there have not been any experimental study used the library service context before. This study will examine the difference between emotional labor strategies on customer satisfaction using the library service setting.

\section{METHOD}

This experiment aimed to investigate the difference between deep acting strategy and surface acting strategy on customer satisfaction and negative WOM. In addition, this study also examined the role of customer satisfaction as the mediation variable between emotional labor strategy and negative WOM. The conceptual framework of this study presented in Figure 1. 


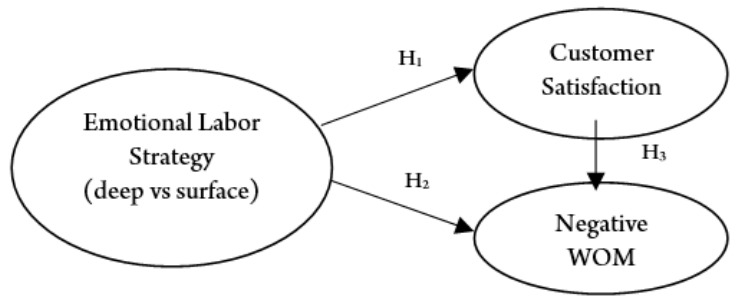

Figure 1. Conceptual Framework

\section{Participants}

The characteristics of the participant are female student and $20-23$ years old (46.9\% were 20 years old). Only female participants were involved in this experiment. This consideration is based on three factors: (1) both of the actors in the video were females; (2) females tend to be easier to express their emotion that males (Barrett \& Bliss-Moreau, 2009); and (3) emotion regulation is more frequently used among females than males (Nolen-Hoeksema, 2012). Previous research found that females have better response to emotion and involve more emotion than males (Lewis, 2000; Demetriou et al., 2009).

The participants were college students from state and private universities in Makassar, South Sulawesi, Indonesia. The recruitment process was conducted through an announcement. This announcement was manually disseminated. There were seventy-one participants who voluntarily joined in this study. From seventyone participants, there were nine respondents who have been eliminated because of the discrepancy with experiment manipulation. Thus, a total of sixty-two participants voluntary in this research. Participants were placed into two groups: deep acting group $(\mathrm{N}=34)$ and surface acting group $(\mathrm{N}=28)$.

\section{Material}

\section{Informed Consent}

Participant's agreement to voluntarily participate in this study was manifested through the informed consent. Information regarding study objective, experiment procedure, and participants right was clearly stated in informed consent. Participants were asked to fill the signature column if they agree.

\section{Customer Satisfaction Scale}

Customer satisfaction was measured with the scale adaptation of Bakar and Himam (2009). Customer satisfaction scale of Bakar dan Himam (2009) consisted of twenty-two items and involved five aspects: reliability, responsiveness, assurance, empathy, and tangibles. The scale has been shown to have good internal consistency $\alpha=0.95$. For example, one of the items was: "The service was given in well-timed with the service schedule". Participants measured the scale by rating the answer option from 1 (Strongly Disagree) to 4 (Strongly Agree). However, due to the consideration in several items could not be assessed in this study, the researcher only used 17 items. For example, this is one of the inappropriate items: "The librarian always tries to fulfill the customer request even in the crowded situation".

\section{Negative WOM Scale}

Negative WOM was measured by a scale of Grégoire et al. (2009). The scale has been shown to have good internal consistency $\alpha=$ 0.91. For example, one of the items in this study was: "I will tell the inconvenience that I felt in this company to other people". The measurement of this scale ranged from 1 (Strongly Disagree) to 4 (Strongly Agree).

\section{Manipulation Check}

One item of this questionnaire was: "The librarian in the video served the library's customer with". Manipulation check provided two answer options: (1) sincere service, or (2) insincere service. Manipulation check form was delivered to all participants after completing the negative WOM scale.

\section{Emotional Labor Strategy Video}

The stimulus in this experiment used deep acting and surface acting video (Amaliah et al., 2019). Those videos portrayed the interaction between customer and employee in the library as depicted on Figure 2. Each of deep acting and surface acting strategy video took approximately four minutes. The instruction of the video was: "You will be served a video. Your task in only watching the video carefully". 


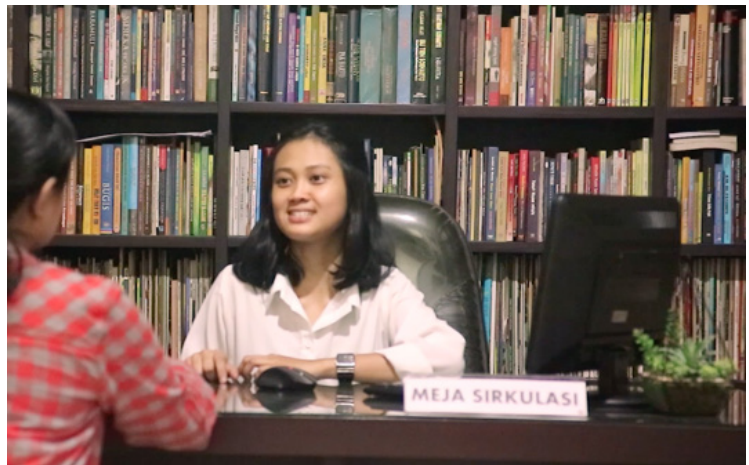

(a) Deep Acting

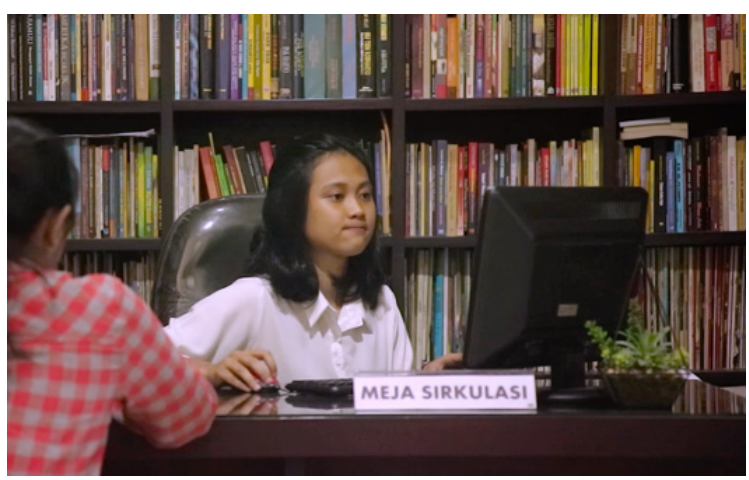

(b) Surface Acting

Figure 2. Experiment Stimulus

\section{Procedure}

This study used between participant experiment design by distributing participants randomly into two groups: deep acting versus surface acting. This study was conducted in the laboratory room of Psychology Faculty, Universitas Negeri Makassar. When the participant arrived, the experimenter welcomed them. Then, the participant was given time to read and sign informed consent. If the participant agreed, the experiment would continue to the instruction. The experimenter showed the deep acting or surface acting videos to participants. The experimenter asked the participants to watch the video carefully. The participants watch the video through the laptop which connected to the headphone, so participants can hear the audio clearly. The difference between the two videos was in the interaction model performed by actors.

\section{Deep Acting Video}

In the deep acting video, the actor showed responsive service by helping the consu- mer need. The employee provided clear information, so the consumer felt helped. The service delivery was also combined with sincere smile expression and friendly intonation several times.

\section{Surface Acting Video}

The actor acted as the employee showed the service interaction by performing the less sincere smile expression and tended to focus on the computer screen, instead of making eye contact with the customer. The employee performance was less responsive and not providing clear information. Thus, the customer asked more questions. Furthermore, the actor presented the flat intonation and less friendly to customers.

Figure 3 show that after watching the video, participants were asked to complete the customer satisfaction scale, negative WOM scale, and manipulation check form. The experimenter ensured that all scales have been filled, then closed the experiment and said thanks to all participants.

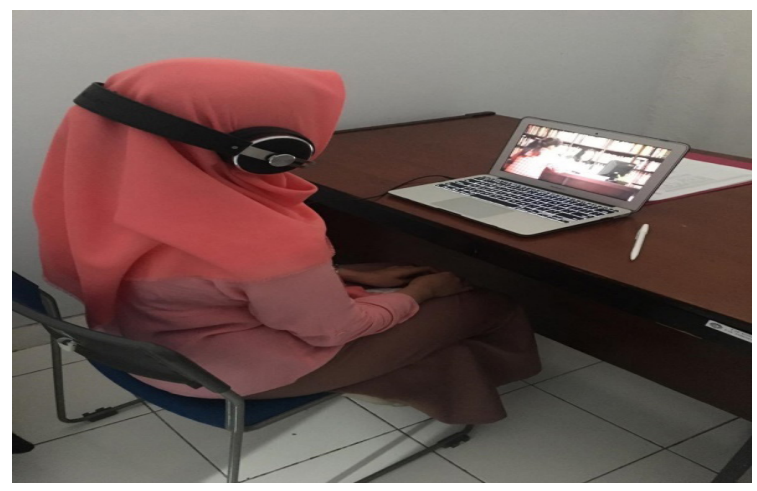

Figure 3. Experiment Process

\section{Data analysis}

Table 1 display measurement of hypothesis 1 and hypothesis 2 was conducted by using the $\mathrm{t}$-test to find the difference between deep acting and surface acting strategy on customer satisfaction and negative WOM. The measurement of hypothesis 3 using the linear regression approach with simple linear moderation model PROCESS macro SPSS software. 
Table 1. Estimation of Emotional Labor Strategy on Negative WOM, mediated by Customer Satisfaction

\begin{tabular}{lllll}
\hline & $\boldsymbol{b}$ & SE & $\boldsymbol{t}$ & $\boldsymbol{p}$ \\
\hline Constant & 4.58 & .13 & 33.07 & .00 \\
$\begin{array}{l}\text { Emotional } \\
\text { Labor Strategy }\end{array}$ & -1.05 & .09 & -11.65 & .00 \\
$\begin{array}{l}\text { (DAvsSA) } \\
\begin{array}{l}\text { Customer } \\
\text { Satisfaction }\end{array}\end{array}$ & -.61 & .21 & -2.88 & .00 \\
\hline
\end{tabular}

Note: DAvsSA = Deep Acting versus Surface Acting

\section{RESULT AND DISCUSSION}

\section{Manipulation Check}

The result of the manipulation check showed that from a total of 71 participants, only 62 can be analyzed, therefore nine participants were eliminated from this study because the answer was not appropriate with the experiment condition.

\section{Validity and Reliability Measurement}

Table 2 reveal that validity and reliability test of customer satisfaction scale demonstrated that 1 item invalid, so it remained 16 items. Total of coefficient correlation of the remaining items ranged from 0.43 to 0.77. Cronbach's Alpha resulted in the reliability $\alpha=0.89$. In the negative WOM scale, Cronbach's Alpha was $\alpha=0.65$. Reliability of negative WOM scale stand in moderate level (Taber, 2018). All valid items ranged from 0.31 to 0.56 .

Table 2. Validity and Reliability Scale

\begin{tabular}{llll}
\hline Scale & $\begin{array}{l}\text { Cronbach's } \\
\text { Alpha }\end{array}$ & $\begin{array}{l}\text { Corrected } \\
\text { Item-Total } \\
\text { Correlation }\end{array}$ & $\begin{array}{l}\mathbf{N} \text { of } \\
\text { Items }\end{array}$ \\
\hline $\begin{array}{l}\text { Customer } \\
\text { Satisfaction }\end{array}$ & .89 & $.43-.77$ & 16 \\
\hline $\begin{array}{l}\text { Negative } \\
\text { WOM }\end{array}$ & .65 & $.31-.56$ & 3 \\
\hline
\end{tabular}

The Differences between Surface Acting and Deep Acting Strategy on Customer Satisfaction The result of this study showed the significant difference of emotional labor between the surface acting group and deep acting group on customer satisfaction, $t(60)=11.65, p<0.05$ (2-tailed), $95 \%$ CI [0.87 - 1.23]. T-test proved that deep acting strategy performed the higher customer satisfaction $\left(\mathrm{M}_{\text {deep-acting }}=3.53, \mathrm{SD}=0.31\right)$, compared with surface acting group $\left(\mathrm{M}_{\text {surface-acting }}=2.48, \mathrm{SD}=\right.$ $0.41)$. This result supported the hypothesis 1.

\section{The Differences between Surface Acting and Deep Acting Strategy on Negative WOM}

Figure 4 demonstrate the experimental study which found the significant difference of emotional labor strategy between surface acting group and deep acting group on negative WOM, $\mathrm{t}(60)=$ -3.12 , p < 0.05 (2-tailed), 95\% CI [-0.80 - 0.17]. Ttest proved that participants in deep acting group performed less negative WOM (Mdeep-acting = $2.10, \mathrm{SD}=0.63)$, compared with surface acting group (Msurface-acting $=2.59, \mathrm{SD}=0.58$ ). This result supported the hypothesis 2 .

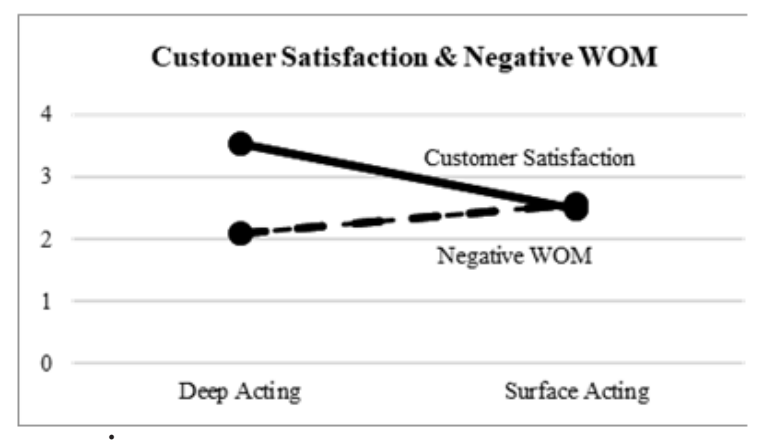

Figure 4. Emotional Labor Strategy on

\section{Effect of Customer Satisfaction as Mediation Variable between Emotional Labor Strategy and Negative WOM}

Regression Analysis using PROCESS procedure Model 4 found that customer satisfaction moderation demonstrated the significant, $\mathrm{b}=$ 0.63 , 95\% BCa CI [0.21-1.12]. This analysis revealed that there is an indirect effect of emotional labor strategy on negative WOM with customer satisfaction as mediation variable. The result of mediation supported hypothesis 3 of this study 
Resekiani Mas Bakar et al./ Switching Expression or Emotion: Emotional Labor Strategy on Negative....

The result of this study demonstrated the difference in emotional labor strategies on customer satisfaction and negative WOM. In addition, this study also found that customer satisfaction play as the indirect effect between emotional labor strategy and negative WOM. Deep acting and surface acting strategy will indirectly influence the consumers to perform either positive or negative WOM, through the role of customer satisfaction variable. This finding can be seen from the average difference of customer satisfaction in deep acting and surface acting strategy. The participants in the deep acting group performed higher satisfaction, compared with the participants in surface acting strategy. Similarly, this pattern was also found for the intention of negative WOM for each group. The participants of the deep acting group performed the lower negative WOM, compared with a surface acting group. The difference of the judgment can be seen in each of response to negative WOM scale $64.3 \%$ of total participants in the surface acting group preferred to tell the inconvenience they experienced to other people. $32 \%$ of total participants in surface acting stated the intention to warn other people to not use the library anymore. While the participants in the deep acting group only reached $12 \%$.

This experimental study has proved that emotional labor strategy had an effect on customer satisfaction. The result of this study found that deep acting strategy performed a more positive influence on customer satisfaction. In contrast, surface acting showed a negative influence to customer satisfaction. The employee who displays a deep acting strategy regarded more satisfied by customers, rather than the employee who displays surface acting strategy.

The employee who performs the sincere emotion (deep acting) will directly influence the customer's emotional feeling during the service interaction (Hennig-Thurau et al., 2006). Previous research which related emotional labor (deep acting and surface acting) towards the customer satisfaction found that deep acting strategy performs more positive impacts to the customer as well as the service quality (Groth \& Hennigthurau, 2009). Emotional labor strategy plays an important role in regulating employee's emotion, attitude, and behavior during the interaction with a customer. The customer's judgment towards the service quality relates to the emotion display performed by the employee and the way to regulate the emotional condition.

Emotional exchange process between employee and customer affects the customer's experience and perception about service quality (Tsai, 2001). The employee who performs the deep acting strategy is able to modify the emotion and show the positive emotion, such as eye contact, sincere smile, and friendliness when helping the customer. Work behavior based on need oriented and customer expectation oriented. The characteristic of deep acting strategy is the ability to notice others' need from a customer's perspective. In contrast, the employee who performs surface acting strategy seems to wear a mask during the interaction with the customer (Grandey, 2003). Modification performed by the employee is merely applied in the face area, cause the insincere service to the customer. The customer can feel the fake expression from a service provider and this cause the impression of a standard operational procedure, not the service.

The result of this study proved that deep acting strategy offers the impacts towards the customer satisfaction increase, rather than surface acting. The correlation between emotional labor strategy and customer satisfaction can be explained by emotional contagion mechanism. Emotional contagion is the emotional exchange between two or more people in a certain condition (Hatfield et al., 1994). Positive emotion performed by the employee allows the transmission to the customer during the service process. In contrast, expression modification in surface acting inflicts the flat emotion or even the negative emotion. Employee's sincerity enables the positive emotion to the customer's emotion and judgment when service occurs (Hülsheger et al., 2010). Several studies have proved the influence of customer satisfaction towards the negative WOM (Anderson, 1998; Söderlund, 1998 ; Sivadas \& Jindal, 2017), but it restricted to the measurement of emotional labor effects towards WOM through the customer satisfaction. 
The employee who performs deep acting strategy will enhance customer satisfaction, thus it affects the information spread to other customer based on the positive emotion during the interaction process. Service interaction using surface acting strategy enables the customer to decrease their satisfaction level. Therefore, the customer tends to convey the negative WOM regarding the inconvenience they encountered to other customers. In contrast, the customer who feels satisfied will show the emotional bond with the service provider. This bond enables the customer to convey positive WOM to other people (Anderson, 1998). The consumer who obtains satisfaction will involve more in the positive WOM than the consumer who obtains no satisfaction (Holmes \& Lett, 1977).

The result of this study similar to the previous study that revealed informational influence as one of the factors that influence people to engage in WOM (Luarn et al., 2016). The customer has the motivation to affect others by providing some information regarding the product or service. These factors affect the relationship between customer satisfaction and WOM: (1) the willingness to help other people and (2) decreasing the emotional dissonance. The customer who feels the low service quality because of the surface acting will share the negative WOM to warn other people. The consumer will empower themselves in order to share the information with other people as social exchange and self-motivation.

Emotion dissonance that happens from surface acting expression can decrease the customer's judgment regarding satisfaction. Emotion dissonance performed by the employee can transmit to other customers. Emotion transmission can inflict the negative emotion for customers. This negative emotion drives the customer to spread negative information due to the inconvenience that has been encountered. On the other hand, the service condition when the employee performs the sincerity can enhance customer satisfaction. Emotional contagion enables customers to experience a positive emotional exchange. This positive emotional exchange, it also drives consumers to share their positive experience and feeling to other people.

\section{CONCLUSION AND RECOMMENDATION}

This study answered the previous study between emotional labor and negative WOM. Emotional labor strategy can affect the negative WOM both directly and indirectly. When emotional labor affect the negative WOM indirectly, the customer satisfaction plays as a mediator. Deep acting strategy has greater influence to increase customer satisfaction and diminish the negative WOM. Thus, for manager, customer satisfaction should be the main focus, especially in service setting to improve their business by performing deep acting strategy to avoid the impact of negative WOM.

Notwithstanding, this study has some limitations which can be considered for the next researchers. First, the participants in this study were college students from Makassar. Therefore, it caused a result generalization problem. It is really required for the next research to involve the respondents from different areas. Second, this study applied the video as the experimental stimuli. The next researcher can modify the experiment stimuli by using narration or direct actor that interact with participants. Third, this study had measured the impacts of emotional labor from the consumer's perspective and mediated by customer satisfaction. The next study can apply other mediation variables to obtain different result. Fourth, WOM scale had the less strong reliability, so it requires more considerations to be applied in the next study.

\section{REFERENCES}

Anderson, E. (1998). Customer Satisfaction and Word of Mouth. Journal of Service Research, 1(1), 5-17.

Bakar, R. M., \& Himam, F. (2009). Efektivitas Pelatihan Pelayanan dalam Meningkatkan Pengetahuan Pelayanan, Kualitas Pelayanan, dan Kepuasan Pengguna Perpustakaan. Jurnal Intervensi Psikologi, 1(2), 179-194.

Barrett, L. F., \& Bliss-Moreau, E. (2009). She's Emotional. He's Having a Bad Day: Attributional Explanations for Emotion Stereotypes. Emotion, 9(5), 649-658.

Brotheridge, C. M., \& Lee, R. T. (2002). Testing a 
Resekiani Mas Bakar et al./ Switching Expression or Emotion: Emotional Labor Strategy on Negative....

Conservation of Resources Model of the Dynamics of Emotional Labor. Journal of Occupational Health Psychology, 7(1), 57-67.

Casidy, R., \& Shin, H. (2015). The Effects of Harm Directions and Service Recovery Strategies on Customer Forgiveness and Negative Word-of-Mouth Intentions. Journal of Retailing and Consumer Services, 27(11), 103-112.

Cho, Y., Rutherford, B. N., \& Park, J. (2013). The Impact of Emotional Labor in a Retail Environment. Journal of Business Research, 66(5), 670-677.

Demetriou, H., Wilson, E., \& Winterbottom, M. (2009). The Role of Emotion in Teaching: are there Differences Between Male and Female Newly Qualified Teachers' Approaches to Teaching? Educational Studies, 35(4), 449-473.

Du, J., Fan, X., \& Feng, T. (2011). Multiple Emotional Contagions in Service Encounters. Journal of the Academy of Marketing Science, 39(3), 449-466.

East, R., Hammond, K., \& Lomax, W. (2008). Measuring the Impact of Positive and Negative Word of Mouth on Brand Purchase Probability. Prisma Social, 25(3), 215-224.

Elliott, D., \& Charlton, L. (2016). A Preliminary Investigation Into the Use of the Emotional Contagion Effect in the Exercise Environment. Comprehensive Psychology, 5, 1-9.

Grandey, A. A. (2000). Emotion Regulation in the Workplace: a New Way to Conceptualize Emotional Labor. Journal of Occupational Health Psychology, 5(1), 95-110.

Grandey, A. A. (2003). When "the Show Must Go on": Surface Acting and Deep Acting as Determinants of Emotional Exhaustion and Peer-Rated Service Delievery. Academy of Management Journal, 46(1), 86-96.

Grandey, A.A., Fisk, G. M., Mattila, A. S.,Jansen, K.J., \& Sideman, L. A. (2005). Is "Service with a Smile" Enough? Authenticity of Positive Displays During Service Encounters. Organizational Behavior and Human Decision Processes, 96(1), 38-55.

Grégoire, Y., Tripp, T. M., \& Legoux, R. (2009). When Customer Love turns into Lasting Hate: the Effects of Relationship Strength and Time on Customer Revenge and Avoidance. Journal of marketing, 73(6), 18-32.

Groth, M., \& Hennig-Thurau, T. (2009). Customer Reactions to Emotional Labor: the Roles of Employee Acting Strategies and Customer Detection Accuracy. Academy of Management
Journal, 52(5), 958-974.

Ha, Y. W., \& Park, M. C. (2013). Antecedents of Customer Satisfaction and Customer Loyalty for Emerging Devices in the Initial Market of Korea: an Equity Framework. Psychology and Marketing, 30(8), 676-680.

Hatfield, E., Cacioppo, J. T., \& Rapson, R. L. (1993). Emotional Contagion. Current Directions in Psychological Science, 2(3), 96-100.

Hatfield, E., Cacioppo, J. T., \& Rapson, R. L. (1994). Emotional Contagion: Studies in Emotion and Social Interaction. United Stated of America: Cambridge University Press.

Hennig-Thurau, T., Groth, M., Paul, M., \& Gremler, D. D. (2006). Are All Smiles Created Equal? How Emotional Contagion and Emotional Labor Affect Service Relationships. Journal of Marketing, 70(3), 58-73.

Hochschild, A. R. (1983). The Managed Heart: Commercialization of Human Feeling. California: University of California Press.

Holmes, J. H., \& Lett, J. D. (1977). Product Sampling and Word of Mouth. Journal of Advertising Research, 17(5), 35-40.

Huang, P.-F., \& Dai, C.-W. (2010). The Impacts of Emotional Contagion and Emotional Labor Perception on Employees' Service Performance. International Journal of Electronic Business Management, 8(1), 68-79.

Hülsheger, U. R., Lang, J. W. B., \& Günter, W. M. (2010). Emotional Labor, Strain, and Performance: Testing Reciprocal Relationships in a Longitudinal Panel Study. Journal of Occupational Health Psychology, 15(4), 505-521.

Iglesias, O., Markovic, S., \& Rialp, J. (2019). How Does Sensory Brand Experience Influence Brand Equity? Considering the Roles of Customer Satisfaction, Customer Affective Commitment, and Employee Empathy. Journal of Business Research, 96(3), 343-354.

Ismoyo, N. B., Hadiwidjojo, D., Rahman, F., \& Rahayu, M. (2017). Service Quality Perception's Effect on Customer Satisfaction and Repurchase Intention. European Business and Management, 3(3), 37-46.

Keller, E. D. (2007). Unleashing the Power of Word Of Mouth: Creating Brand Advocacy to Drive Growth. Journal of Advertising Research, 47(4), 448-452.

King, R. A., Racherla, P., \& Bush, V.D. (2014). What We Know and Don't Know About Online 
Word-of-Mouth : a Review and Synthesis of the Literature. Journal of Interactive Marketing, 28(3), 167-183.

Kruml, S. M., \& Geddes, D. (2014). Exploring the Dimensions of Emotional Labor : the Heart of Hochschild'S Work Exploring the Dimensions of Emotional Labor. Management Communication Quarterly, 14(1), 8-51.

Lewis, K. M. (2000). When Leaders Display Emotion: How Followers Respond to Negative Emotional Expression of Male and Female Leaders. Journal of Organizational Behavior, 21(2), 221-234.

Liu, Y., Perrewé, P. L., Hochwarter, W. A., \& Kacmar, C. J. (2004). Dispositional Antecedents and Consequences of Emotional Labor at Work. Journal of Leadership \& Organizational Studies, 10(4), 12-25.

Luarn, P., Huang, P., Chiu, Y. P., \& Chen, I. J. (2016). Motivations to Engage in Word-of-Mouth Behavior on Social Network Sites. Information Development, 32(4), 1253-1265.

Mazzarol, T., Sweeney, J. C., \& Soutar, G. N. (2007). Conceptualizing Word-of-Mouth Activity, Triggers and Conditions: an Exploratory Study. European Journal of Marketing, 41(11), 1475-1494.

Mesmer-Magnus, J. R., Dechurch, L. A., \& Wax, A. (2011). Moving Emotional Labor Beyond Surface and Deep Acting: a DiscordanceCongruence Perspective. Organizational Psychology Review, 2(1), 6-53.

Neves, L., Cordeiro, C., Scott, S. K., Castro, S. L., \& Lima, C. F. (2018). High Emotional Contagion and Empathy are Associated with Enhanced Detection of Emotional Authenticity in Laughter. Quarterly Journal of Experimental Psychology, 71(11), 2355-2363.

Nguyen, H. T., Nguyen, H., Nguyen, N. D., \& Phan, A. C. (2018). Determinants of Customer Satisfaction and Loyalty in Vietnamese LifeInsurance Setting. Sustainability, 10(4), 1-16.

Nolen-Hoeksema, S. K. (2012). Emotion Regulation and Psychopathology: the Role of Gender. The Annual Review of Clinical Psychology, 8(1), 161-187.

Oliver, R. L. (1999). Whence Consumer Loyalty? Journal of Marketing, 639(1), 33-44.

Ranaweera, C., \& Prabhu, J. (2003). On the Relative Importance of Customer Satisfaction and Trust as Determinants of Customer Retention and Positive Word of Mouth. Journal of
Targeting, Measurement and Analysis for marketing, 12(1), 82-90.

Sivadas, E., \& Jindal, R. P. (2017). Alternative Measures of Satisfaction and Word of Mouth. Journal of Services Marketing, 31(2), 119-130.

Söderlund, M. (1998). Customer Satisfaction and its Consequences on Customer Behavior Revisited: the Impact of Different Levels of Satisfaction on Word-of-Mouth, Feedback to the Supplier and Loyalty. International Journal of Service Management Industry, 9(2), 169-188.

Suchánek, P., Richter, J., \& Králová, M. (2015). Customer Satisfaction, Product Quality and Performance of Company. Review of Economic Perspective, 14(4), 329-344.

Suchánek, P., Richter, J., \& Králová, M. (2017). Customer Satisfaction with Quality of Products of Food Busines. Journal of Prague Economic Papers, 26(1), 19-35.

Szymanski, D. M., \& Henard, D. H. (2001). Customer Satisfaction: a Meta-Analysis of the Empirical Evidence. Journal of the Academy of Marketing Science, 29(1), 16-35.

Taber, K. S. (2018). The use of Cronbach's alpha when developing and reporting research instruments in science education. Research in Science Education, 48(6), 1273-1296.

Taghizadeh, H., Taghipourian, M. J., \& Khazaei, A. (2013). The Effect of Customer Satisfaction on Word of Mouth Communication. Research Journal of Applied Sciences, Engineering and Technology, 5(8), 2569-2575.

Tsai, W. C. (2001). Determinants and Consequences of Employee Displayed Positive Emotions. Journal of Management, 27(4), 497-512.

Vázquez-Casielles, R., Suárez-Álvarez, L., \& RíoLanza, A.-B. (2013). The Word of Mouth Dynamic: How Positive (and Negative) Wom Drives Purchase Probability an Analysis of Interpersonal and Non-Interpersonal Factors. Journal of Advertising Research, 53(1), 43-60.

Wangenheim, F. (2005). Postswitching Negative Word of Mouth. Journal of Service Research, $8(1), 67-78$.

Yasvari, T. H., Ghassemi, R. A., \& Rahrovy, E. (2012). Influential Factors on Word of Mouth in Service Industries (the Case of Iran Airline Company ). International Journal of Learning and Development, 2(5), 227-242. 